\title{
Preliminary observations of caulerpin accumulation from the invasive Caulerpa cylindracea in native Mediterranean fish species
}

\author{
S. Felline ${ }^{1, *}$, E. Mollo ${ }^{2}$, A. Cutignano ${ }^{2}$, L. Grauso ${ }^{2}$, F. Andaloro ${ }^{3}$, L. Castriota ${ }^{3}$, \\ P. Consoli ${ }^{3}$, M. Falautano ${ }^{3}$, M. Sinopoli ${ }^{3}$, A. Terlizzi ${ }^{4,5}$ \\ ${ }^{1}$ Dipartimento di Scienze e Tecnologie Biologiche ed Ambientali, Università del Salento, CoNISMa, 73100 Lecce, Italy \\ ${ }^{2}$ Istituto di Chimica Biomolecolare, Consiglio Nazionale delle Ricerche, 80078 Pozzuoli, Italy \\ ${ }^{3}$ Istituto Superiore per la Protezione e la Ricerca Ambientale (ISPRA), 98143 Palermo, Italy \\ ${ }^{4}$ Dipartimento di Scienze della Vita, Università degli Studi di Trieste, CoNISMa, 34127 Trieste, Italy \\ ${ }^{5}$ Stazione Zoologica Anton Dohrn, 80121 Napoli, Italy
}

\begin{abstract}
Recent studies have shown that the Mediterranean white sea bream Diplodus sargus includes the invasive green alga Caulerpa cylindracea in its diet, with consequent metabolic and enzymatic alterations. As a result of this novel alimentary habit, the bioactive algal red pigment caulerpin has been detected in its tissues. However, this may not be an isolated case: other fish species have also been reported to feed on C. cylindracea, although the possible accumulation of caulerpin in their tissues has not yet been investigated. In this report, we analysed stomach contents and caulerpin levels in the native sparid species Spondyliosoma cantharus, Sarpa salpa, and Diplodus vulgaris, and in the scarid Sparisoma cretense, along with the Lessepsian siganid Siganus luridus. C. cylindracea was found in the stomachs of all but one fish species, the exception being $S$. cretense, in which prey items could not be determined due to the high degree of digestion. Chemical analysis of fish tissues revealed that only $S$. cantharus and $S$. salpa accumulated caulerpin, while no traces of the compound were detected in the other species. Despite intense research efforts on natural products obtained from $C$. cylindracea, a complete picture of the impacts caused by fish including this alga in their diet has not been elucidated. The identification of caulerpin in other Mediterranean native fish suggests a need for further research in order to assess the possible transfer of such molecules to humans through seafood consumption.
\end{abstract}

KEY WORDS: Invasive species $\cdot$ Bioaccumulation $\cdot$ Alien metabolites $\cdot$ Food webs $\cdot$ Mediterranean

\section{INTRODUCTION}

Invasive species are causing negative impacts across all regions of the Mediterranean, including many marine protected areas, with the consequent failure of management and conservation practices to maintain native biodiversity (Simberloff 2000). The Pelagian Islands have not escaped this general trend

\footnotetext{
${ }^{*}$ Corresponding author: serena.felline@unisalento.it
}

and have now been colonized by many exotic species of Indo-Pacific origin, including fish (e.g. Siganus luridus and Fistularia commersonii; Azzurro et al. 2007) and invasive green algae (e.g. Caulerpa cylindracea; Serio et al. 2006).

However, although the densities, distribution and temporal patterns of non-indigenous species (NIS) have been widely investigated over the last few years,

(0) The authors 2017. Open Access under Creative Commons by Attribution Licence. Use, distribution and reproduction are unrestricted. Authors and original publication must be credited. Publisher: Inter-Research · www.int-res.com 
very little is known about the ecological impact of their invasion on Mediterranean biodiversity. Generally, when an alien species is reported in a new environment, it has already established a close relationship with native wildlife. In this regard, the invasion by the green alga $C$. cylindracea (whose identity and origin remained obscure for a decade after the first record) is proving to be a serious threat to native species in the invaded environments, including fish of commercial interest. Indigenous to the southwestern coast of Australia, C. cylindracea has spread across the entire Mediterranean basin, and its impressive and constant expansion is not expected to decline in the near future (Bulleri \& Benedetti-Cecchi 2008, Montefalcone et al. 2015). Due to its invasiveness, the alga has been included in the list of the 100 worst NIS of the Mediterranean Sea (Streftaris \& Zenetos 2006). Given that C. cylindracea forms dense meadows in vast areas of the Mediterranean, it is also reasonable to expect that its bioactive secondary metabolites, the most well-known and studied of which are the bisindole alkaloid caulerpin, the sesquiterpene caulerpenyne, and the mixture of hydroxy amides caulerpicin, may start exerting critical impacts on native communities (Mollo et al. 2015). Several biological activities have been described for these compounds, potentially contributing to the competitive success of this alga in the invaded habitats (Brunelli et al. 2000, Erickson et al. 2006, Raniello et al. 2007, Rocha et al. 2007).

Recently, an altered health status and a nutritional impoverishment in flesh of the white sea bream Diplodus sargus were found to be related to the action of C. cylindracea metabolites. D. sargus has been reported to consume high amounts of $C$. cylindracea, and, as a consequence of these novel feeding habits, accumulates caulerpin in its tissues (Terlizzi et al. 2011). The level of caulerpin in fish tissues (used as a trophic marker of a C. cylindracea-based diet) is not only related to the appearance of cellular and physiological alterations (Felline et al. 2012, Gorbi et al. 2014), but also to significantly altered muscle fatty acid composition, with a reduction of essential polyunsaturated fatty acids of the $n-3$ and $n-6$ series (Felline et al. 2014). These finding led to the hypothesis that similar negative effects, yet unrecognized, could be occurring in other fish populations. Indeed, several species have been observed to graze on $C$. cylindracea (e.g. Klein \& Verlaque 2008).

The aim of this study was to assess if, as a consequence of the addition of $C$. cylindracea to the diet, other fish species accumulate caulerpin and are potentially exposed to their toxic effects. Specifically, we characterized the diet of 5 fish species, namely the omnivore Spondyliosoma cantharus, the herbivorous Sarpa salpa and Sparisoma cretense, the generalist carnivore Diplodus vulgaris and the non-indigenous herbivore Siganus luridus. Subsequently, we explored the possible accumulation of C. cylindracea metabolites in the liver and muscle tissues of the fish. The goal of this study was to provide further information on the transfer of bioactive molecules from marine invasive species into wild fish, paving the way for assessing both their impact in the invaded areas and the potential risks to humans associated with fish consumption.

\section{MATERIALS AND METHODS}

\section{Sampling}

Three individuals each of Diplodus vulgaris, Sarpa salpa, Spondyliosoma cantharus, Siganus luridus and Sparisoma cretense were collected by spear fishing performed by a SCUBA diver in November 2013 at Punta Cappellone $\left(35^{\circ} 31.297^{\prime} \mathrm{N}, 12^{\circ} 35.554^{\prime} \mathrm{E}\right)$ and Taccio Vecchio $\left(35^{\circ} 31.444^{\prime} \mathrm{N}, 12^{\circ} 35.953^{\prime} \mathrm{E}\right)$ in the Isole Pelagie marine protected area off the northern coast of Lampedusa Island, Italy. Each specimen was weighed to the nearest $0.1 \mathrm{~g}$ and total length was measured to the nearest $0.1 \mathrm{~mm}$. Stomachs were removed by severing the esophagus near the buccal cavity and the intestine just anterior to the pyloric caeca; the contents were preserved in $70 \%$ ethyl alcohol. Approximately $1 \mathrm{~g}$ of fish muscle was excised from above the lateral line, beginning near the operculum along the side of the fish. Liver and muscle tissue from each individual were frozen and maintained at $-20^{\circ} \mathrm{C}$ until processed for chemical analyses.

\section{Quantification of caulerpin}

Levels of caulerpin accumulation in liver and muscle tissue of each specimen were measured by ultraperformance liquid chromatography/mass spectrometry (UPLC-MS/MS) following the procedure described in Gorbi et al. (2014). Briefly, lyophilized liver and muscle tissues (25 and $50 \mathrm{mg}$, respectively) were extracted with ethyl acetate. Before extraction, indolacrilic acid methyl ester was added as an internal standard in lyophilized liver and muscle tissues $(20 \mu \mathrm{l}$ of solutions, 80 and $10 \mu \mathrm{g} \mathrm{ml}^{-1}$, respectively). Organic extracts were evaporated under reduced pressure and 
reconstituted in $1 \mathrm{ml}$ of methanol. UPLC-MS/MS analyses were performed with 3 technical replicates, and are reported as mean $( \pm \mathrm{SE}, \mathrm{n}=3)$ values in $\mu \mathrm{g} \mathrm{g}^{-1}$.

\section{Analysis of stomach contents}

Prey items were identified to the lowest possible taxonomic level. All prey categories were enumerated, blotted and weighed separately to the nearest $\mathrm{mg}(0.001 \mathrm{~g})$.

Frequency of occurrence $\left(O_{i} \%\right.$; the percentage of non-empty stomachs containing the $i$ th particular prey item) and percentages by weight of prey $\left(W_{i} \%\right.$; the ratio of the weight of the $i$ th prey category $W_{i}$ to the total weight of the stomach content $W_{\mathrm{T}}$ ) were calculated. These indices were then combined to calculate, for each item, the modified index $\left(\mathrm{MI}_{i}\right)$ of relative importance (Hayse 1990), such that for a specific food category $i, \mathrm{MI}_{i}$ becomes

$$
\mathrm{MI}_{i}=\left[\frac{\left(W_{i} \times O_{i}\right.}{\sum_{i}^{n}\left(W_{i} \times O_{i}\right.}\right] \times 100
$$

where $n$ is the total number of food categories considered at a given taxonomic level.

\section{RESULTS}

A total of 15 specimens, 3 of each species, with a mean $( \pm \mathrm{SE})$ total length of $23.7 \pm 0.8 \mathrm{~cm}$ were analyzed; all biometrics data are reported in Table 1.

Analyses of stomach contents were carried out on all fish species, with the exception of Sparisoma cretense, in which food items had been reduced to an indiscernible mass. Caulerpa cylindracea was found in the stomachs of all individuals of Sarpa salpa and Siganus luridus, whereas only 1 specimen both of Diplodus vulgaris and Spondyliosoma cantharus had algae in the gut. According to the MI index, C. cylindracea was particularly important in the diet of $S$. cantharus $(\mathrm{MI}=$ $28 \%$ ), whereas it constituted only a minor item in the diet of the other species (Table 2, Fig. 1).

Chemical analysis of fish tissues revealed that only $S$. cantharus and S. salpa accumulated caulerpin, while no trace was detected in the other species. Lower levels of caulerpin were found in the herbivorous $S$. salpa (from 5.62 to $8.36 \mu^{-1} \mathrm{~g}^{-1}$ of lyophilized liver) than in $S$. cantharus, where caulerpin levels in the liver ranged from 0.36 to $33.82 \mu \mathrm{g} \mathrm{g}^{-1}$ (Table 1). In general, lower levels of caulerpin were found in muscle than in liver tissues (Table 1).
Table 1. Biometric data and caulerpin levels in liver and white muscle tissue of all analyzed fish, grouped by species (3 individuals for each species). For each individual, the mean $( \pm \mathrm{SE}, \mathrm{n}=3$ ) caulerpin level (Cau) is expressed as $\mu \mathrm{g}$ per $\mathrm{g}$ of lyophilized tissue. nd: not detectable

\begin{tabular}{|c|c|c|c|}
\hline $\begin{array}{l}\text { Total length } \\
(\mathrm{cm})\end{array}$ & $\begin{array}{l}\text { Weight } \\
\text { (g) }\end{array}$ & $\begin{array}{l}\text { Cau liver } \\
\left(\mu g^{-1}\right)\end{array}$ & $\begin{array}{c}\text { Cau muscle } \\
\left(\mu g g^{-1}\right)\end{array}$ \\
\hline \multicolumn{4}{|c|}{ Spondyliosoma cantharus } \\
\hline 18.5 & 109.7 & $0.36 \pm 0.21$ & $0.06 \pm 0.06$ \\
\hline 18.5 & 109.7 & $0.36 \pm 0.21$ & $0.06 \pm 0.06$ \\
\hline 20.5 & 135.7 & $33.82 \pm 4.14$ & $8.24 \pm 1.19$ \\
\hline 23.5 & 213.1 & $6.57 \pm 1.44$ & $1.09 \pm 0.60$ \\
\hline \multicolumn{4}{|c|}{ Diplodus vulgaris } \\
\hline 25.8 & 280.3 & nd & nd \\
\hline 23.3 & 229.2 & nd & nd \\
\hline 23.0 & 207.1 & nd & nd \\
\hline \multicolumn{4}{|c|}{ Sparisoma cretense } \\
\hline 30.7 & 534.8 & nd & nd \\
\hline 29.7 & 480.0 & nd & nd \\
\hline 20.5 & 144.0 & nd & nd \\
\hline \multicolumn{4}{|l|}{ Sarpa salpa } \\
\hline 22.0 & 164.3 & $8.36 \pm 0.72$ & $1.87 \pm 0.47$ \\
\hline 22.5 & 170.5 & $6.35 \pm 0.60$ & $1.23 \pm 0.12$ \\
\hline 20.5 & 120.0 & $5.62 \pm 0.39$ & $0.30 \pm 0.21$ \\
\hline \multicolumn{4}{|c|}{ Siganus luridus } \\
\hline 25.7 & 394.2 & nd & nd \\
\hline 24.7 & 319.7 & nd & nd \\
\hline 24.9 & 356.2 & nd & nd \\
\hline
\end{tabular}

\section{DISCUSSION}

In this report, we provide preliminary data indicating that the accumulation of dietary caulerpin, formerly only observed in the white sea bream, also occurs in 2 other native edible fish species known to consume Caulerpa cylindracea, namely Spondyliosoma cantharus and Sarpa salpa, with higher levels found in the former. No caulerpin accumulation was detected in the native species Diplodus vulgaris and Sparisoma cretense, or in the non-native fish Siganus luridus.

Caulerpin showed a special propensity to accumulate in liver tissues, as already observed in Diplodus sargus (Terlizzi et al. 2011), whereas the lowest levels were found in muscle. Differences in the distribution of caulerpin can be explained in relation to the different lipid content in fillet and liver, and the general positive relationship that is known to occur in fish between tissues with higher lipid content (adipose tissue, gonads, and liver) and the load of hydrophobic pollutants (e.g. Garcia et al. 2000, Davis et al. 2002, Monosson et al. 2003, Blanes et al. 2009). Moreover, many chemicals that are assimilated by the gut reach high concentrations in the liver because they 
Table 2. Analysis of fish stomach contents ( $\mathrm{n}=3$ individuals for each species) expressed as percentage of frequency of occurrence $(O \%)$ and index of relative importance $(\mathrm{MI} \%)$. Whenever possible, items were grouped by Order or Class

\begin{tabular}{|c|c|c|c|c|c|c|c|c|}
\hline & \multicolumn{2}{|c|}{ Diplodus vulgaris } & \multicolumn{2}{|c|}{ Sarpa salpa } & \multicolumn{2}{|c|}{ Spondyliosoma cantharus } & \multicolumn{2}{|c|}{ Siganus luridus } \\
\hline & $O \%$ & MI\% & $O \%$ & MI\% & $O \%$ & MI\% & $O \%$ & $\mathrm{MI} \%$ \\
\hline Caulerpa cylindracea & 33.3 & 3.9 & 100 & 3.6 & 100 & 27.5 & 100 & 0.3 \\
\hline Algae & 66.7 & 17.9 & 100 & 96.4 & 0 & 0 & 100 & 99.7 \\
\hline Tracheophyta (Liliopsida) & 66.7 & 28.7 & 0 & 0 & 33.3 & 1 & 0 & 0 \\
\hline Chetognatha (undetermined) & 0 & 0 & 0 & 0 & 33.3 & 0.2 & 0 & 0 \\
\hline Arthropoda (Harpacticoida) & 0 & 0 & 0 & 0 & 33.3 & 0 & 0 & 0 \\
\hline Arthropoda (Leptostraca) & 33.3 & 0.1 & 0 & 0 & 0 & 0 & 0 & 0 \\
\hline Arthropoda (Mysida) & 0 & 0 & 0 & 0 & 33.3 & 0 & 0 & 0 \\
\hline Arthropoda (Amphipoda) & 33.3 & 1.4 & 0 & 0 & 0 & 0 & 0 & 0 \\
\hline Arthropoda (Decapoda) & 66.7 & 51 & 0 & 0 & 33.3 & 3.6 & 0 & 0 \\
\hline Arthropoda (Crustacea und.) & 0 & 0 & 0 & 0 & 33.3 & 6.6 & 0 & 0 \\
\hline Mollusca (Gastropoda) & 100 & 31.2 & 0 & 0 & 0 & 0 & 0 & 0 \\
\hline Mollusca (Bivalvia) & 66.7 & 6.4 & 0 & 0 & 0 & 0 & 0 & 0 \\
\hline Mollusca (Scaphopoda) & 33.3 & 0 & 0 & 0 & 0 & 0 & 0 & 0 \\
\hline Annelida (Polychaeta) & 100 & 5.4 & 0 & 0 & 0 & 0 & 0 & 0 \\
\hline Sipuncula (undetermined) & 66.7 & 0.1 & 0 & 0 & 0 & 0 & 0 & 0 \\
\hline Bryozoa (undetermined) & 33.3 & 0 & 0 & 0 & 0 & 0 & 0 & 0 \\
\hline Cnidaria (Siphonophorae) & 0 & 0 & 0 & 0 & 66.7 & 3.9 & 0 & 0 \\
\hline Chordata (Actinopteri) & 0 & 0 & 0 & 0 & 100 & 57.2 & 0 & 0 \\
\hline
\end{tabular}

pass the liver first, and because in the hepatic sinusoids the slow blood flow increases residence time (Pelkonen \& Ahokas 2009).

The rates of absorption, metabolism, and elimination of toxicants could certainly vary among species and strains within species, as well as among sex, size and age classes. Variability in the accumulation of caulerpin among D. sargus individuals has been reported in the literature (Felline et al. 2012, 2014, Gorbi et al. 2014) but the biological mechanisms underlying intra-specific variability remain unclear. This study has presented an initial exploration and a starting point for further research on an extension of the phenomena observed in D. sargus to other organisms at different trophic levels.

Conclusions from this study must be drawn with caution because of the small number of individuals analyzed. However, despite the low sample size, our results do confirm that the red pigment caulerpin does enter the food chain and accumulates in the tissues of edible fish species. In the light of these results, subsequent efforts should be directed toward an evaluation of the possible impact of algal metabolites on the health status and reproductive potential of $S$. cantharus and S. salpa. These results could then be compared with data on D. sargus in order to determine if there are any differences between different trophic compartments, and to understand whether herbivorous fish species exhibit more efficient pathways than omnivores with respect to detoxification of plant-derived toxins. This is a pressing need, since altered demographic dynamics in $S$. salpa (the main herbivore on Mediterranean rocky reefs and seagrass meadows), eventually caused by the consumption of C. cylindracea, would likely result in major changes to the structure and functioning of lower and higher trophic-level communities (Bariche et al. 2004, Goren \& Galil 2005, Sala et al. 2011). Future directions of research in this area should also take into account that the absence of caulerpin in the

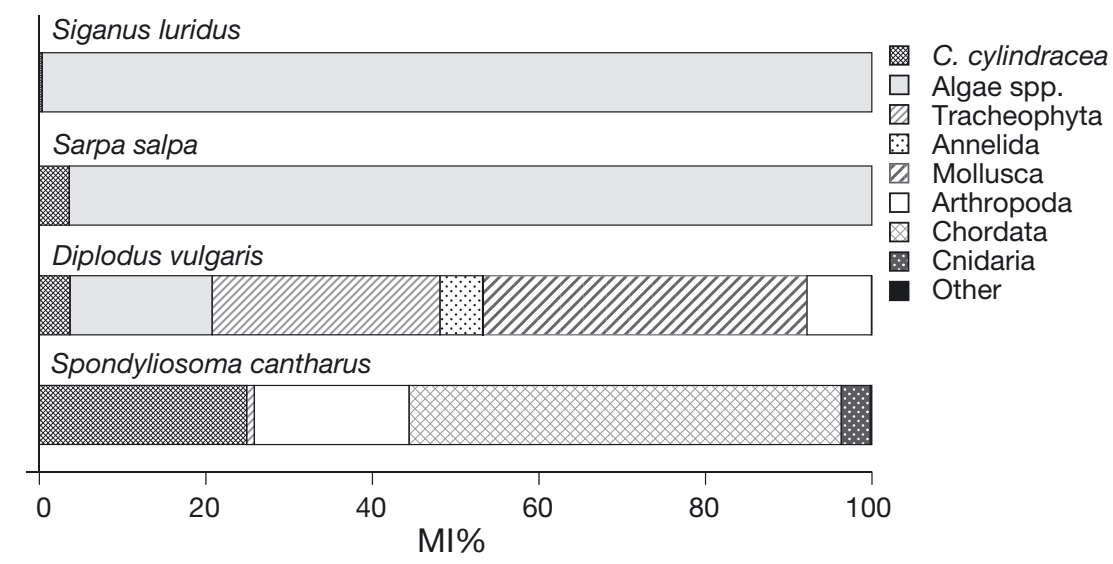

Fig 1. Diet composition of the investigated species according to the modified index of relative importance $(\mathrm{MI} \%)$. Items were grouped by phylum; those that comprised $<1 \%$ of the diet of all fish species were included in 'Other' 
Lessepsian migrant $S$. luridus might be due to either a lower exposure to the seaweed (or lower rate of consumption), or to more efficient pathways of detoxification.

In conclusion, the present study has shown that the accumulation of caulerpin from consumption of $C$. cylindracea is not limited to D. sargus, but involves at least 2 other native Mediterranean fish species. This information sets the stage for a more thorough evaluation of the mechanisms of accumulation and/or detoxification of caulerpin, both in native and nonnative species.

Acknowledgements. Species analyzed in this study are not critically endangered species, and according to Italian (D.L.vo 26/2014) and EU (Directive 63/2010) legislation on the care and use of experimental animals, fishing does not require approval by an animal ethics committee if animals are sacrificed on-site.Financial support provided by MIUR (The Ministry of Education, Universities and Research) (PRIN 2012, CAULERFISH projects), and by the EU FP7 PERSEUS Project (Grant Agreement No. 287600). This study is framed within the Marine Strategy Framework Directive (MSFD) Programme.

\section{LITERATURE CITED}

Azzurro E, Carnevali O, Bariche M, Andaloro F (2007) Reproductive features of the non-native Siganus luridus (Teleostei, Siganidae) during early colonization at Linosa Island (Sicily Strait, Mediterranean Sea). J Appl Ichthyol 23:640-645

Bariche M, Letourneur Y, Harmelin-Vivien M (2004) Temporal fluctuations and settlement patterns of native and Lessepsian herbivorous fishes on the Lebanese coast (eastern Mediterranean). Environ Biol Fishes 70:81-90

* Blanes MA, Serrano R, López FJ (2009) Seasonal trends and tissue distribution of organochlorine pollutants in wild and farmed gilthead sea bream (Sparus aurata) from the Western Mediterranean Sea and their relationship with environmental and biological factors. Arch Environ Contam Toxicol 57:133-144

Brunelli M, Garcia-Gil M, Mozzachiodi R, Scuri MRR, Traina G, Zaccardi ML (2000) Neuro-toxic effects of caulerpenyne. Prog Neuro-Psychopharmacol Biol Psychiatry 24:939-954

Bulleri F, Benedetti-Cecchi L (2008) Facilitation of the introduced green alga Caulerpa racemosa by resident algal turfs: experimental evaluation of underlying mechanisms. Mar Ecol Prog Ser 364:77-86

Davis JA, May MD, Greenfield BK, Fairey R and others (2002) Contaminant concentrations in sport fish from San Francisco Bay, 1997. Mar Pollut Bull 44:1117-1129

Erickson AA, Paul VJ, Van Alstyne KL, Kwiatkowski LM (2006) Palatability of macroalgae that use different types of chemical defenses. J Chem Ecol 32:1883-1895

* Felline S, Caricato R, Cutignano A, Gorbi S and others (2012) Subtle effects of biological invasions: cellular and

Editorial responsibility: Helmut Segner, Bern, Switzerland physiological responses of fish eating the exotic pest Caulerpa racemosa. PLOS ONE 7:e38763

*Felline S, Mollo E, Ferramosca A, Zara V, Regoli F, Gorbi S, Terlizzi A (2014) Can a marine pest reduce the nutritional value of Mediterranean fish flesh? Mar Biol 161: 1275-1283

*Garcia LM, Porte C, Albaiges J (2000) Organochlorinated pollutants and xenobiotic metabolizing enzymes in W. Mediterranean mesopelagic fish. Mar Pollut Bull 40:764-768

* Gorbi S, Giuliani ME, Pittura L, d'Errico G and others (2014) Could molecular effects of Caulerpa racemosa metabolites modulate the impact on fish populations of Diplodus sargus? Mar Environ Res 96:2-11

Goren M, Galil BS (2005) A review of changes in the fish assemblages of Levantine Inland and marine ecosystems following the introduction of non-native fishes. J Appl Ichthyol 21:364-370

Hayse JW (1990) Feeding habits, age, growth, and reproduction of Atlantic spadefish Chaetodipterus faber (Pisces: Ephippidae) in South Carolina. Fish Bull 88: 67-83

KKlein J, Verlaque M (2008) The Caulerpa racemosa invasion: a critical review. Mar Pollut Bull 56:205-225

Mollo E, Cimino G, Ghiselin MT (2015) Alien biomolecules: a new challenge for natural product chemists. Biol Invasions 17:941-950

* Monosson E, Ashley JTF, McElroy AE, Woltering D, Elskus AA (2003) PCB congener distributions in muscle, liver and gonad of Fundulus heteroclitus from the lower Hudson River Estuary and Newark Bay. Chemosphere 52: 777-787

Montefalcone M, Morri C, Parravicini V, Bianchi CN (2015) A tale of two invaders: divergent spreading kinetics of the alien green algae Caulerpa taxifolia and Caulerpa cylindracea. Biol Invasions 17:2717-2728

Pelkonen O, Ahokas J (2009) Pharmacokinetics: How does the body handle drugs? In: Majewski H (ed) Pharmacology, Vol 1. EOLSS Publishers, Oxford, p 148-172

Raniello R, Mollo E, Lorenti M, Gavagnin M, Buia MC (2007) Phytotoxic activity of caulerpenyne from the Mediterranean invasive variety of Caulerpa racemosa: a potential allelochemical. Biol Invasions 9:361-368

* Rocha FD, Soares AR, Houghton PJ, Pereira RC, Kaplan MAC, Teixeira VL (2007) Potential cytotoxic activity of some Brazilian seaweeds on human melanoma cells. Phytother Res 21:170-175

* Sala E, Kizilkaya Z, Yildirim D, Ballesteros E (2011) Alien marine fishes deplete algal biomass in the eastern Mediterranean. PLOS ONE 6:e17356

* Serio D, Alongi G, Catra M, Cormaci M, Furnari G (2006) Changes in the benthic algal flora of Linosa Island (Straits of Sicily, Mediterranean Sea). Bot Mar 49: 135-144

Simberloff D (2000) No reserve is an island: marine reserves and nonindigenous species. Bull Mar Sci 66:567-580

Streftaris N, Zenetos A (2006) Alien marine species in the Mediterranean. The 100 'Worst Invasives' and their impact. Mediterr Mar Sci 7:87-118

Terlizzi A, Felline S, Lionetto MG, Caricato R, Perfetti V, Cutignano A, Mollo E (2011) Detrimental physiological effects of the invasive alga Caulerpa racemosa on the Mediterranean white seabream Diplodus sargus. Aquat Biol 12:109-117

Submitted: June 2, 2016; Accepted: December 26, 2016 Proofs received from author(s): February 6, 2017 